\title{
Teoretyczne i empiryczne aspekty internacjonalizacji polskich przedsiębiorstw ${ }^{1}$
}

\author{
Pawet Krzewicki*
}

\begin{abstract}
Proces internacjonalizacji stat sie jednym z głównych obszarów zainteresowania ekonomii oraz nauki o zarzadzaniu. Zachodzace $w$ wymiarze globalnym zmiany, obejmujace liberalizację handlu oraz postęp technologiczny, istotnie wplywają na warunki prowadzenia dziatalności gospodarczej. Ekspansja na rynki zagraniczne staje się jednym z kluczowych wymiarów rozwoju przedsiębiorstwa funkcjonujaccego w konkurencyjnej gospodarce rynkowej. Celem autora artykułu jest przybliżenie Czytelnikowi problematyki umiędzynarodowienia działalności przez polskie podmioty gospodarcze. Autor, stosując holistyczne podejście do omawianego zjawiska, prezentuje ramy teoretyczne, oparte na dotychczasowym dorobku ekonomii oraz nauk o zarzadzaniu, a także dokonuje przegladu literatury pod katem badań empirycznych. Analiza została wzbogacano o wyniki prowadzonego, na Wydziale Zarzadzania Uniwersytetu Warszawskiego, projektu pt. „Wprowadzenie euro a konkurencyjność polskich przedsiębiorstw na rynkach zagranicznych”.
\end{abstract}

Słowa kluczowe: internacjonalizacja przedsiębiorstw, proces umiędzynarodowienia, teoria handlu, model internacjonalizacji, badanie empiryczne.

Nadesłany: 20.11.2016 | Zaakceptowany do druku: 27.12.2016

\section{Empirical Aspects of Internationalization of Polish Enterprises}

The process of internationalization has become one of the main areas of interest in the field of economic and management science. Global changes such as liberalization of trade and technological progress substantially influence the conditions of running a business. Expansion into foreign markets is becoming one of the key dimensions of development of enterprises that are operating in a competitive market economy.

The aim of this article is to explain the phenomenon of internationalization of enterprises, in the case of Poland. The author develops a holistic approach to the discussed problem by presenting a theoretical framework - based on economic and management theories - and he makes a literature review in the empirical research context. Moreover, the analysis includes the results of "The introduction of euro currency vs. competitiveness of Polish enterprises on foreign markets" project, conducted by the author at the Faculty of Management at the University of Warsaw.

Keywords: internationalization of enterprises, process of internationalization, theory of trade, model of internationalization, empirical research.

Submitted: 20.11.2016 | Accepted: 27.12.2016

JEL: F23, D21, D22

* Paweł Krzewicki - mgr, doktorant, Wydziału Zarządzania, Uniwersytet Warszawski.

Adres do korespondencji: Wydziału Zarządzania, Uniwersytet Warszawski, ul Szturmowa 1/3, 02-678 Warszawa; e-mail: pawel.krzewicki@gmail.com. 


\section{Wprowadzenie}

Podmioty gospodarcze stanowią filar współczesnej gospodarki rynkowej. Ograniczona ilość zasobów oznacza konieczność rywalizacji pomiędzy przedsiębiorstwami dążącymi do realizacji określonych celów, w tym maksymalizacji zysku, ale także wymusza kooperacje między nimi. Kwestie odnoszące się do konkurencyjności przedsiębiorstw oraz fragmentaryzacji produkcji stały się jednymi z głównych obszarów zainteresowania zarówno ekonomii, jak i nauk o zarządzaniu. Prezentowane $\mathrm{w}$ ramach tych dyscyplin teorie oraz badania empiryczne koncentrują się na funkcjonowaniu pojedynczych podmiotów oraz na relacjach występujących pomiędzy nimi i szeroko postrzeganym otoczeniem.

Obserwowane od momentu wejścia do Unii Europejskiej przemiany zachodzące $\mathrm{w}$ polskiej gospodarce oraz procesy $\mathrm{w}$ wymiarze globalnym, związane m.in. z postępem technologicznym, determinują decyzje przedsiębiorstw dotyczące charakteru i kształtu prowadzonej przez nie działalności. $\mathrm{Z}$ jednej strony liberalizacja handlu stała się szansą rozwoju ze względu na dostęp do większego i bardziej chłonnego rynku zbytu. Z drugiej natomiast - przyczynia się do zwiększenia konkurencji na rynku lokalnym, na którym w większej liczbie pojawiają się podmioty $\mathrm{z}$ innych państw, w tym szczególnie korporacje transnarodowe. W tym kontekście ekspansja międzynarodowa stanowi naturalny element strategii rozwoju przedsiębiorstwa.

Proces internacjonalizacji polskiej gospodarki, w tym podmiotów gospodarczych, charakteryzuje się wysoką dynamiką zmian. Rosnące zainteresowanie literatury przedmiotu, wyrażone w licznych badaniach empirycznych, pozwala uchwycić zmiany zachodzące m.in. w stopniu, tempie, kierunkach oraz formie umiędzynarodowienia przedsiębiorstw. Szczególnie istotna, z perspektywy poruszanej problematyki, jest jej wieloaspektowość, która powinna wykorzystywać dotychczasowy dorobek ekonomii oraz nauk o zarządzaniu.

Celem autora jest omówienie teoretycznych aspektów procesu internacjonalizacji przedsiębiorstw oraz przybliżenie dotychczasowego dorobku literatury przedmiotu w tym zakresie. W pierwszej części niniejszego tekstu skoncentrowano się na ewolucji teorii, w znacznym stopniu rozwijanych niezależnie, z zakresu handlu międzynarodowego oraz produkcji międzynarodowej. Zwrócono również uwagę na główne modele umiędzynarodowienia. Następnie zaprezentowane zostały wybrane badania empiryczne polskich przedsiębiorstw, realizowane w latach 2005-2013. Ostatnim elementem niniejszego artykułu jest przedstawienie wyników analizy przeprowadzonej w ramach projektu pt. Wprowadzenie euro a konkurencyjność polskich przedsiębiorstw na rynkach zagranicznych.

\section{Ramy teoretyczne procesu internacjonalizacji}

Rozważania dotyczące umiędzynarodowienia przedsiębiorstw wymagają nakreślenia ram teoretycznych omawianych procesów. Pozostaje to istotne $\mathrm{z}$ perspektywy analizy stopnia internacjonalizacji czy szerzej - z poziomu konkurencyjności na rynkach zagranicznych, ale także umożliwia krytyczny przegląd dotychczasowych koncepcji, których ewolucja obrazuje zmiany zachodzące we współczesnej gospodarce. W tym kontekście szczególne znacznie miały postęp technologiczny oraz wzrost powiązań pomiędzy państwami, które poprzez obniżenie kosztów transakcyjnych przyczyniły się do wzrostu wolumenu handlu.

Początkowo analiza wymiany międzynarodowej rozpatrywana była wyłącznie na poziomie wzajemnych relacji pomiędzy państwami. Prowadzona w ten sposób analiza dostarczała informacji o korzyściach oraz kosztach otwartości gospodarczej, a także ich wpływu na poziom dobrobytu. Szczególnie w naukach ekonomicznych, rola przedsiębiorstwa $\mathrm{w}$ omawianych procesach przez długi czas była marginalizowana i nie stanowiła przedmiotu głębszej refleksji.

Pierwszą, tradycyjną teorią wymiany międzynarodowej stał się rozwijany pomiędzy XVI a XVIII wiekiem merkantylizm zakładający, że bogactwo państwa związane jest z ilością posiadanego przez nie kruszcu (Nowak i Niewiadomska, 2014, s. 7). Konsekwencją dla polityki gospodarczej kraju była koncentracja na zwiększaniu poziomu eksportu, którego wzrost zapewnia pomnażanie zasobów złota oraz srebra. Punktem wyjścia w krytyce merkantylizmu był brak możliwości utrzymania dodatniego bilansu handlowego w długiej perspektywie. Zda- 
niem szkockiego ekonomisty Davida Hume'a, napływ dużej ilości kruszcu przyczynia się do wzrostu cen, prowadząc w ten sposób do obniżenia konkurencyjności oferowanych dóbr (Budnikowski, 2006, s. 40).

Krytyka merkantylizmu została zawarta również w klasycznej teorii handlu międzynarodowego. Adam Smith zwrócił uwagę, że handel odbywający się pomiędzy państwami przynosi korzyści obu stronom wzajemnej wymiany (Smith, 2007, s. 8-35). Koncepcja ta została rozwinięta przez Davida Ricardo, który, wykorzystując pojęcie kosztu alternatywnego, sformułował teorię przewagi komparatywnej (Krugman i Obstfeld, 2007, s. 43). Podejście to, w odróżnieniu od koncepcji kosztu absolutnego, koncentrowało się na porównaniu względnych nakładów związanych z wytworzeniem poszczególnych dóbr. Pozwoliło to wyjaśnić oraz uzasadnić handel odbywający się pomiędzy państwami, z których jedno posiada przewage absolutną $\mathrm{w}$ produkcji wszystkich dóbr handlowych.

Istotny wkład w rozwój teorii handlu międzynarodowego wniósł John Stuart Mill, który postulował konieczność uwzględnienia popytu oraz podaży krajów bioracycy udział w wymianie. Stało się to podstawą późniejszych rozważań Alfreda Marshalla, który prowadząc badania na szerokiej grupie towarów, wprowadził pojęcie faktycznego stosunku wymiany (ang. terms of trade).

Omawiane teorie nie koncentrowały się na wyjaśnieniu występującej specjalizacji państw w konkretnych sektorach oraz gałęziach gospodarki. Zagadnienie to stało się podstawą teorii obfitości zasobów sformułowanej, w dużym stopniu niezależnie od siebie, przez Eli Heckschera oraz Berlia Ohlina. Zgodnie z nią państwo powinno produkować oraz eksportować dobro wymagające wykorzystania w większym stopniu zasobów, w które jest relatywnie lepiej wyposażone (Zielińska-Głębocka i Rynarzewski, 2008, s. 98). Weryfikacji przedstawionej hipotezy podjął się Wassily Leontief, który na podstawie badań empirycznych wskazał, że Stany Zjednoczone mimo obfitego wyposażenia w kapitał, specjalizują się w eksporcie dóbr wymagających relatywnie dużych nakładów pracy (Nowak i Niewiadomska, 2014, s. 17). Wyjaśnieniem występującego paradoksu jest zróżnicowanie w wydajności pracy występujące pomiędzy krajami, na co wska- zały późniejsze badania (Bożyk i Misala, 1998, s. 93).

Dynamiczny rozwój nauki oraz towarzyszący mu postęp technologii stały się podstawą do formułowania neotechnologicznych teorii wymiany międzynarodowej. Michael Posner, formułując koncepcje luki technologicznej, zwrócił uwagę na występujące pomiędzy państwami zróżnicowanie w stopniu zaawansowana technologicznego. Uchylenie założenia o jednakowej funkcji produkcji dla wszystkich krajów stało się również podstawą sformułowanej przez Raymona Vernona teorii cyklu życia produktu. Autor, wychodząc poza dotychczasowe ramy teorii handlu międzynarodowego, zwrócił uwagę na różne formy działalności międzynarodowej, w tym inwestycje zagraniczne. Pozwoliło to na wyodrębnienie trzech faz obecności produktu na rynku (Vernon, 1966, s. 195).

Obserwowany w II poł. XX wieku stały wzrost wolumenu handlu w znacznym stopniu koncentrował się na wymianie odbywającej się pomiędzy krajami rozwiniętymi, które pozostawały zbliżone pod względem technologii, poziomu innowacyjności oraz wyposażenia w czynniki produkcji. Stało się to podstawą opracowanej przez Paula Krugmana nowej teorii handlu, który uchylając założenia dotyczące doskonałej konkurencji, zwrócił uwagę na występowanie wewnętrznych korzyści skali związanych $\mathrm{z}$ dostępnością danego towaru na większej liczbie rynków (Krugman, 1981, s. 959-973). W opracowanym przez autora modelu uwzględnione zostało również zamiłowanie konsumentów do różnorodności (Krugman, 1979, s. 471-472).

Nowa teoria handlu stała się podstawowym narzędziem wyjaśniającym rosnące znaczenie regionalnych ugrupowań integracyjnych o charakterze gospodarczym. Niemniej jednak zawarte w niej założenie o firmie reprezentatywnej wskazywało, że wszystkie przedsiębiorstwa charakteryzują się jednakową zdolnością do umiędzynarodowiania swojej działalności, co pozostawało sprzeczne z przeprowadzonymi badaniami empirycznymi (Cieślik, Michałek i Michałek, 2012, s. 68). Z tej perspektywy istotny wkład do rozwoju teorii handlu międzynarodowego wniósł Marc Melitz, który, wykorzystując model opracowany przez Paula Krugmana, uwzględnił zróżnicowanie firm ze względu na ich produktywność (Melitz, 2003, 1695-1696). Dodatkowo 
autor dokonał rozróżnienia na koszty stałe oraz zmienne, związane $\mathrm{z}$ procesem wejścia na nowe rynki (Melitz, 2003, s. 1698).

Teorie handlu międzynarodowego, powstajace na gruncie nauk ekonomicznych, stanowią podstawę do analizy wymiany towarowej odbywajacej się pomiedzy państwami. Pozwalają one zrozumieć przyczyny eksportu oraz ich wpływ na zmiany dobrobytu, ale w znacznym stopniu marginalizują rolę przedsiębiorstwa $\mathrm{w}$ tym procesie. $\mathrm{Z}$ tego powodu stały się narzędziem niewystarczającym w badaniu procesu internacjonalizacji, który ze względu na rosnący poziom fragmentaryzacji produkcji, w coraz większym stopniu koncentrował się na kapitałowych formach zaangażowania na rynkach zagranicznych. Przyczyniło się to do wyodrębnienia grupy koncepcji, określanych w literaturze przedmiotu mianem teorii produkcji międzynarodowej, które wykorzystywały wcześniejszy dorobek nauk o zarządzaniu.

Zwiększenie aktywności przedsiębiorstw na rynkach zagranicznych skłaniało do prowadzenia badań nad czynnikami mającymi kluczowe znaczenie w procesie podejmowania decyzji o internacjonalizacji. Stephen Hymer, formułując teorię przewagi monopolistycznej, zwrócił uwagę na występowanie kosztów wejścia na dany rynek związanych z jego nieznajomością, różnicami językowi oraz kulturowymi. Przedstawione bariery wraz $\mathrm{z}$ kosztami transakcyjnymi oraz ryzykiem kursowym, które w znacznej mierze mają charakter trwały, należy traktować jako przewagę konkurencyjną firm lokalnych (Hymer, 1976, s. 28-31).

W kontekście kosztów związanych z ekspansją na rynki zagraniczne, kluczowe, zdaniem Stephena Hymera, jest posiadanie przez firmę specyficznej przewagi (ang. firm-specific advantage) wynikającej z wewnętrznych czynników i procesów. Zdaniem autora, wywołujace ja czynniki moga mieć różny charakter, ale zawsze związane są z niedoskonale funkcjonującym rynkiem (Hymer, 1976). Klasyfikacji źródeł przewagi monopolistycznej dokonał Charles Kindleberger, wskazujac na brak doskonałej konkurencji zarówno na rynku czynników produkcji, a także dóbr finalnych, występowanie korzyści skali oraz restrykcyjna politykę państwa.

Charakter przewagi monopolistycznej stał się przedmiotem licznych badań oraz rozważań teoretycznych. Literatura przedmiotu koncentrowała się głównie na zasobach niematerialnych, które oprócz posiadanych wewnątrz przedsiębiorstwa umiejętności, doświadczenia oraz wiedzy obejmowały również działania marketingowe ukierunkowane na kreowanie marki (Caves, 1996, s. 3 ).

Brak doskonałej konkurencji stał się również podstawowym założeniem rozwijanej równolegle teorii reakcji oligopolistycznej, dokonującej analizy na poziomie sektorów gospodarki. Frederick T. Knickerbocker, prowadzac badania empiryczne na grupie przedsiębiorstw amerykańskich podejmujących bezpośrednie inwestycje zagraniczne, zaobserwował zależność występującą pomiędzy liczbą podmiotów funkcjonujących w branży a podejmowaniem kapitałowych form internacjonalizacji. Podmioty, podejmujac decyzje o umiędzynarodowieniu, kierują się wcześniejszymi działaniami przedsiębiorstw konkurujących w ramach oligopolu i podążają za liderem danej branży.

Teoria reakcji oligopolistycznej pozwala zrozumieć motywacje przedsiębiorstw w branżach o ograniczonej liczbie podmiotów o podobnej wielkości i sile oddziaływania na rynek. Poza obszarem jej zainteresowania pozostają przyczyny ekspansji na rynki zagraniczne podmiotów będących liderami.

Wyjaśnienia wyboru bezpośrednich inwestycji zagranicznych jako formy ekspansji na rynki zagraniczne dostarcza teoria internalizacji. Wychodzi ona $\mathrm{z}$ zapoczątkowanej przez Ronalda Coase'a oraz rozwiniętej przez Olivera Williamsona koncepcji kosztów transakcyjnych, które wynikają z niedoskonałego funkcjonowania rynku. Przedsiębiorstwo, podejmując kapitałowe formy umiędzynarodowienia, dokonuje hierarchizacji firmy polegającej na koordynacji łańcucha wartości. Pozwala to na substytucje rynku zewnętrznego przez transakcje wewnętrzne, które eliminujac dostęp pośredników w procesie alokacji zasobów, ograniczają dostep do informacji (Wąsowska, 2011, s. 29). Celem takiego działania jest zajęcie korzystnej pozycji na rynku poprzez wykorzystanie posiadanej przewagi monopolistycznej.

$\mathrm{Z}$ perspektywy procesu umiędzynarodowienia istotnym aspektem w procesie decyzyjnym przedsiębiorstwa jest wybór rynku ekspansji zagranicznej. Problematyka lokalizacji poszczególnych form internacjonali- 
zacji stała się przedmiotem licznych analiz skupiających się na wyodrębnieniu kluczowych czynników sukcesu. Dokonując krytycznego przeglądu literatury przedmiotu, John H. Dunning wyodrębnił trzy grupy przesłanek obejmujących determinanty ekonomiczne, biznesowe oraz strukture polityczną (Dunning, 2003, s. 282-283). Niezależnie od siebie tworzone były również inne klasyfikacje, w ramach których koncentrowano się m.in. na czynnikach o charakterze rynkowym, a także handlowym (Rymarczyk, 2004, s. 41). Warto jednak zauważyć, że teoria lokalizacji wskazuje na potencjalne korzyści bądź koszty związane $\mathrm{z}$ prowadzeniem działalności na danym rynku.

Przedstawione teorie produkcji międzynarodowej miały charakter jednoczynnikowy i koncentrowały się na poszczególnych elementach ekspansji na rynki zagraniczne. Natomiast proces internacjonalizacji ma charakter złożony i wymaga uwzględnienia zróżnicowanych motywacji oraz działań przedsiębiorstw (Oczkowska, 2013, s. 71). Największe uznanie zyskała eklektyczna teoria produkcji międzynarodowej, uwzględniająca trzy płaszczyzny umiędzynarodowienia, tj. czynniki (zasoby i umiejętności) umożliwiające świadczące o konkurencyjności międzynarodowej, formę oraz kierunek internacjonalizacji. Zaproponowany przez Johna H. Dunninga model OLI (ang. ownership - location internalisation) stanowił synteze koncepcji przewagi monopolistycznej (nazwanej przez autora przewaga własności), internalizacji oraz lokalizacji (Dunning, 2000, s. 163-164). Wieloaspektowy charakter w połączeniu z łatwością zastosowania oraz możliwością dostosowania do specyfiki danego rynku sprawiły (Gorynia, 2007, s. 103), że stał się jednym $\mathrm{z}$ najczęściej wykorzystywanych sposobów analizy procesów umiędzynarodowienia.

Rozwijane na gruncie ekonomii oraz nauk o zarządzaniu teorie handlu i produkcji międzynarodowej pozwalały określić przyczyny i motywacje umiędzynarodowienia, a także potencjalne korzyści i koszty z nim związane. Koncentracja na czynnikach stymulujących ekspansje na rynki zagraniczne ograniczała możliwość dynamicznej analizy procesów internacjonalizacji, które są rozciągnięte w czasie. Problematyka ta podejmowana była w ramach licznych badań empirycznych, na podstawie których stworzone zostały konkretne modele umiędzynarodowienia przedsiębiorstw.

Pierwsza, a także najbardziej rozpowszechniona w literaturze przedmiotu grupa modeli konwencjonalnych, zwanych również sekwencyjnymi, odwołuje się do teorii wzrostu firmy oraz teorii behawioralnej, postrzegając ekspansje na rynki zagraniczne jako proces o charakterze inkrementalnym (Wąsowska, 2011, s. 33). Punktem wyjścia były badania empiryczne prowadzone przez pracowników Uniwersytetu w Uppsali, którzy dokonali wnikliwej analizy, pod kątem umiędzynarodowienia, rozwoju czterech szwedzkich przedsiębiorstw (Sandvik, Atlas Copso, Facit, Volvo) działających na rynkach zagranicznych. Uzyskane wyniki wskazały, że każda $z$ firm stopniowo zwiększała zaangażowanie w działalność międzynarodową poprzez dostosowanie do warunków zastanych w innych krajach (Johanson i Wiedersheim-Paul, 1975, s. 305).

Na podstawie prowadzonych badań Jan Johanson i Finn Widersheim-Paul opracowali model uppsalski, w ramach którego sformułowali podstawowe konkluzje dotyczące procesu internacjonalizacji. Po pierwsze, rozpoczęcie ekspansji na rynki zagraniczne poprzedzone jest wcześniejszym sukcesem na rynku krajowym oraz odpowiednim poziomem rozwoju. Po drugie, początkowo przedsiębiorstwa wchodzą na rynki bliskie geograficznie i relatywnie dobrze znane, co ułatwia dostęp do informacji oraz ogranicza koszty. Po trzecie, rozpoczynając działalność międzynarodową, podmioty gospodarcze wybierają mniej zaawansowane formy umiędzynarodowienia, które pozwalają ograniczyć ryzyko oraz wymagają mniejszego nakładu kapitału (Johanson i Wiedersheim-Paul, 1975, s. 306).

Sekwencyjny charakter procesu internacjonalizacji skłonił do wyróżnienia poszczególnych faz, które charakteryzowały się odmiennym poziomem zaangażowania zasobów oraz posiadanych informacji. Jan Johanson i Finn Widersheim-Paul zaproponowali klasyfikację wyróżniającą cztery etapy umiędzynarodowienia:

- nieregularna działalność eksportowa polega na zaspokojeniu popytu pochodzącego z innego kraju, ale bez angażowania na nich posiadanych przez firmę zasobów, 
- eksport pośredni z wykorzystaniem niezależnych agentów - oznacza wprowadzenie produktu na rynek zagraniczny oraz zaangażowanie części $\mathrm{z}$ posiadanych zasobów, przyczyniając się do zwiększenia przepływu informacji,

- utworzenie filii handlowej - związane jest z kapitałową formą zaangażowania w innym państwie pozwalającą na większą kontrolę nad produktem oraz przepływem informacji między firmą a jej otoczeniem,

- utworzenie filii produkcyjnej - wymaga zaangażowania jeszcze większej części zasobów w działalność na rynku zagranicznym, ale umożliwia również ograniczenie ryzyka (Johanson i WiedersheimPaul, 1975, s. 306-307).

Model uppsalski zyskał uznanie literatury przedmiotu, stając się jednym z głównych narzędzi wykorzystywanych przy analizie procesu internacjonalizacji. Późniejsze badania empiryczne, które zostały oparte na jego głównych założeniach, pozwoliły na przedstawienie odmiennych klasyfikacji etapów umiędzynarodowienia. Na uwagę zasługuje spojrzenie zaprezentowane przez Tamera Cavusgila, który koncentrując się na przedsiębiorstwach przetwórstwa przemysłowego, wyróżnił trzy stopnie zaangażowania eksportowego (eksperymentalne, aktywne oraz pełne) (Cavusgil, 1984, s. 197).

Początkowo model uppsalski pokazywał w sposób hierarchiczny poszczególne etapy internacjonalizacji, które uzależniał od posiadanego przez przedsiębiorstwo doświadczenia. Jan Johanson oraz Jan-Erick Vahlne uwzględnili dynamiczny charakter ekspansji na rynki zagraniczne, wskazując, że osiągnięcie konkretnego poziomu umiędzynarodowienia rozpoczyna kolejną fazę omawianego procesu. W ramach przedstawionej koncepcji wyróżnione zostały dwa oddziałujące na siebie aspekty internacjonalizacji: statyczny (ang. state) oraz dynamiczny (ang. change). Pierwszy z nich koncentruje sie na posiadanej wiedzy o danym rynku oraz stopniu zaangażowania zasobów. Drugi, aspekt dynamiczny, składa się z bieżącej, operacyjnej działalności przedsiębiorstwa oraz jego decyzji dotyczących poziomu zaangażowania (Johanson i Vahlne, 1977, s. 26-29).

Oparta na badaniach empirycznych krytyka sekwencyjnego procesu internacjonalizacji zwracała uwagę na inne czynniki determinujące podejmowanie ekspansji na rynki zagraniczne. Punktem wyjścia stały się argumenty przedstawione przez twórców modelu uppsalskiego - Jana Johansona oraz Finna Widersheima-Paula - dotyczace przedsiębiorstw funkcjonujących na relatywnie małym rynku oraz posiadajacych duże doświadczenie zdobyte na podobnych rynkach, których umiędzynarodowienie może odbiegać od prezentowanej przez autorów koncepcji (Johanson i Wiedersheim-Paul, 1975, s. 307). Przyczyniło się to do licznych analiz odchodzacych od deterministycznego charakteru internacjonalizacji prezentowanego w modelach konwencjonalnych.

W literaturze przedmiotu pojawiły się badania empiryczne wskazujace, że cześść jednostek gospodarczych jest zdolna do większego zaangażowania, niż wynikało to $\mathrm{z}$ etapowego procesu umiędzynarodowienia. Modele niesekwencyjne dostarczały argumentów, że posiadanie odpowiednich zasobów - w tym szczególnie niematerialnych - pozwala na wcześniejsze zastosowanie bardziej zaawansowanych form internacjonalizacji (ang. leapfrogging). Czynnikami, mającymi istotny wpływ na tempo zachodzących procesów mogą być zarówno globalizacja i towarzyszacy jej postęp technologiczny, jak również zwiększenie poziomu homogeniczności preferencji konsumentów (Gorynia, 2008, s. 86-90).

Modele niekonwencjonalne stają się użytecznym narzędziem analizy przedsiebiorstw określanych mianem „urodzonych globalistów" (ang. born global). W tym przypadku charakterystyczne jest m.in. rozpoczynanie działalności na wielu rynkach jednocześnie, opracowywanie strategii dotyczącej produktu oraz klienta w wymiarze globalnym, a także dążenie do osiągniecia pozycji lidera w branży (Oczkowska, 2013, s. 71). Tendencje dotyczą głównie niewielkich przedsiębiorstw działających na innowacyjnych i technologicznie zaawansowanych rynkach.

Etapowe oraz niekonwencjonalne modele internacjonalizacji postrzegały ekspansje zagraniczna przez pryzmat decyzji podejmowanych przez pojedyncze podmioty. Marginalizowana w ten sposób rola wzajemnych powiązań pomiędzy przedsiębiorstwami, które nabrały znaczenie w efekcie zwiększenia fragmentaryzacji produkcji, stała się podstawą stworzenia sieciowego modelu umiędzynarodowienia. 
Zgodnie $\mathrm{z}$ nim wchodzenie oraz zwiększanie zaangażowania na rynkach zagranicznych uzależnione jest od otoczenia w którym funkcjonuje dana firma. Sieć relacji biznesowych stanowi specyficznych rodzaj zasobu niematerialnego, który działa w sposób substytucyjny w odniesieniu do posiadanej wiedzy oraz doświadczenia przyczyniając się do wyższego poziomu umiędzynarodowienia (Johanson i Vahlne, 1992, s. 9-27).

Zgodnie z modelem sieciowym proces internacjonalizacji odbywa się na dwóch płaszczyznach - przedsiębiorstwa oraz sieci do której należy. Na tej podstawie Jan Johanson i Lars-Gunnar Mattsson wskazali na cztery hipotetyczne sytuacje, w których może znaleźć się podmiot podejmujący ekspansje na rynkach zagranicznych. Pierwsza, „wcześnie zaczynający” (ang. the Early Starter) odnosi się do przedsiębiorstwa posiadającego ograniczone doświadczenie oraz funkcjonującego w ramach rozproszonej sieci o mało istotnych więziach. Zaangażowanie na rynkach zagranicznych umożliwia zajeccie pozycji ,samotnego umiędzynarodowionego" (ang. the Lonely International). „Późno zaczynający” (ang. the Later Starter) określa podmiot nieposiadający doświadczenia w działalności międzynarodowej, ale mający dostęp do zasobów pozostałych członków sieci. Wysoki stopień umiędzynarodowienia przedsiębiorstwa, a także sieci charakteryzuje podmioty gospodarcze zajmujące pozycje ,internacjonała w zinternacjonalizowanym otoczeniu" (Johnason i Mattsson, 1998, s. 298).

Kluczowym aspektem formułowanego podejścia sieciowego jest uwzględnienie pozycji rynkowej przedsiębiorstwa. Analiza czynników sprzyjających umiędzynarodowieniu wymaga analizy mikro-pozycji oraz makropozycji. Pierwsza z nich odnosi się do wzajemnych relacji z pojedynczymi podmiotami funkcjonującymi $\mathrm{w}$ sieci. Makropozycja koncentruje się na tworzeniu i rozwijaniu więzi z siecią traktowaną w sposób holistyczny (Gorynia i Jankowska, 2008, s. 93). Pozwoliło to na wyodrębnienie dwóch kluczowych bodźców internacjonalizacji z perspektywy wzajemnych relacji wewnatrz sieci. Po pierwsze, wchodzac do sieci, w której funkcjonuje jeden $\mathrm{z}$ naszych partnerów, mamy możliwość eksploracji nowych rynków, wykorzystując relacje biznesowe. Po drugie, podejmowanie ekspansji na rynki zagraniczne przez jeden podmiot wymusza podobną reakcję ze strony innych przedsiębiorstw działających w sieci wzajemnych więzi i relacji (Johanson i Vahlne, 2009, s. 1425).

\section{Przegląd dotychczasowych badań empirycznych obejmujących umiędzynarodowienie polskich przedsiębiorstw}

Problematyka umiędzynarodowienia polskich przedsiębiorstw stała się obiektem licznych analiz empirycznych prowadzonych przez ośrodki naukowe oraz firmy konsultingowe. Przeprowadzony przez Mirosława Jarosińskiego przegląd literatury przedmiotu pod tym kątem zidentyfikował 83 badania zrealizowanych na przestrzeni 1990-2010, które w całości bądź części koncentrowały się na procesie internacjonalizacji (Jarosińska, 2013, s. 71).

W niniejszej części pracy omówiono niewielką część badań empirycznych przeprowadzonych w latach 2005-2013, które zdaniem autora pozwalają spojrzeć wieloaspektowo i holistycznie na międzynarodowy wymiar działalności polskich przedsiębiorstw. Uwzględniono badania realizowane na tej samej grupie respondentów w kolejnych latach oraz prowadzone przez ten sam zespół z wykorzystaniem podobnego zestawu pytań. Zastosowanie ujęcia chronologicznego ograniczonego do unikatowych i nowych badań pozwala dokonać wnikliwej analizy zachodzących zmian w określonych ramach czasu.

Pierwsza zidentyfikowana na potrzeby niniejszego artykułu analiza procesu umiędzynarodowienia polskich przedsiębiorstw została zrealizowana przez firmę audytorsko-doradczą KPMG w ramach projektu pt. Ekspansja międzynarodowa polskich przedsiębiorstw. Przeprowadzone na próbie 65. największych firm przemysłowych badanie ankietowe koncentrowało się głównie na poziomie internacjonalizacji branży oraz kierunkach i formach ekspansji zagranicznej (KPMG, 2005, s. 2). Uzyskane wyniki wskazują, że zdecydowana większość (95\%) podmiotów była zaangażowana w dzialalność międzynarodową, w tym eksport okazał się dominującą formą umiędzynarodowienia (54\%). Głównym kierunkiem ekspansji przedsiębiorstw przemysłowych była Unii Europejskiej (86\%), a także państwa Europy Środkowo-Wschodniej (52\%) oraz Azji (34\%). 
Kontynuacją badań empirycznych zrealizowanych przez KPMG było przygotowanie raportu pt. Ekspansja międzynarodowa polskich przedsiębiorstw produkcyjnych opartego na wynikach ankietyzacji losowo dobranej próby 112 podmiotów należących do grupy 1000 największych firm z dominującym udziałem kapitału krajowego. Prowadzenie działalności międzynarodowej w 2009 roku deklarowało 100 firm (89\%), które wykorzystywały głównie eksport swoich produktów $(88 \%)$ oraz współpracę z podmiotami zagranicznymi $(55 \%)$.

Zgodnie $\mathrm{z}$ wynikami wcześniejszych badań głównym kierunkiem ekspansji były kraje Europy Zachodniej (88\%), w tym rynek niemiecki mający największe znacznie z perspektywy przedsiębiorstw produkcyjnych. Odpowiedzi dotyczące udziału przychodów ze sprzedaży zagranicznej w odniesieniu do obrotów ogółem, który kształtował się na poziomie $38 \%$ dla grupy 94 respondentów, wskazują na średni stopień internacjonalizacji.

Agencja Rozwoju Pomorza, przy wsparciu finansowym Unii Europejskiej, przeprowadziła obszerne i cykliczne badania kondycji przedsiębiorstw $\mathrm{z}$ województwa pomorskiego działających w sektorze MSP. Pierwsze badania $\mathrm{w}$ ramach Pomorskiego Obserwatorium Gospodarczego zostały przeprowadzone w 2006 roku na grupie 2129 przedsiębiorstw gospodarczych dobranych w sposób losowy. Uzyskane wyniki wskazują, że w próbie znalazło się $28,6 \%$ podmiotów prowadzących działalność eksportową. Znacznie wyższa skłonnością do internacjonalizacji charakteryzowały się przedsiębiorstwa $\mathrm{z}$ dominującym udziałem kapitału zagranicznego (74,8\%) (Agencja Rozwoju Pomorza, 2007).

W 2008 roku, w ramach kontynuacji zapoczątkowanego 2 lata wcześniej projektu, przeprowadzono analizę 761 przedsiębiorstw pochodzących z bazy przygotowanej na potrzeby pierwotnego badania. Relatywnie mniejszy udział w próbie miały podmioty działające na rynkach zagranicznych $(25,5 \%)$. Statyczny opis kondycji przedsiębiorstw został uzupełniony o analizę dynamiki zmian. Zauważono, że mimo dobrej koniunktury, większa liczba podmiotów zdecydowała się zaprzestać eksportu niż go rozpoczaćc, co zdaniem autorów może świadczyć o niekorzystnym wpływie aprecjacji złotego. W tym czasie zdecydowana większość przedsiębiorstw zaangażowanych na rynkach zagranicznych (62\%) zwiększyła eksport (Agencja Rozwoju Pomorza, 2008).

W ramach Pomorskiego Obserwatorium Gospodarczego kontynuowano badania wyselekcjonowanej grupy przedsiębiorstw w 2009 roku, który charakteryzował się pogorszeniem koniunktury światowej. Wyniki ankietyzacji 982 podmiotów wskazały nieznaczny wzrost (o 1,2 pkt. proc.) udziału eksporterów w próbie względem poprzedniego badania. Zgodnie z oczekiwaniami widoczny był wpływ kryzysu gospodarczego na decyzje dotyczące ekspansji na rynki zagraniczne. W odniesieniu do poprzedniego badania wzrost eksportu widoczny był dla $24 \%$ przedsiębiorstw spośród zaangażowanych w działalność międzynarodową, natomiast spadek jego wartości dotknął $37 \%$ z nich. Agencja Rozwoju Pomorza przebadała także 88 firm utworzonych w latach 2005-2008, które nie mogły uczestniczyć we wcześniejszych badaniach. Zgodnie z sekwencyjnym modelem umiędzynarodowienia znacznie mniejsza część z tych przedsiębiorstw (15,9\%) podjęla ekspansje na rynki zagraniczne (Agencja Rozwoju Pomorza, 2010).

Ostatnia ankietyzacja małych i średnich przedsiębiorstw z województwa pomorskiego miała miejsce w 2012 roku i dotyczyła 695 przedsiębiorstw biorących udział we wcześniejszych edycjach badania. Udział jednostek gospodarczych dokonujących ekspansji na rynki zagraniczne utrzymywał się na zbliżonym poziomie $(25,8 \%)$ i nie odbiegał od wyników obserwowanych w innych krajach Unii Europejskiej. Zauważono, że większość z nich $(58,1 \%)$ traktowało aktywność zagraniczną jako uzupełnienie działalności w kraju macierzystym. Uzyskane odpowiedzi wskazują również, że największa część respondentów zaangażowanych na rynkach zagranicznych $(39,7 \%)$ zwiększyła wartość eksportu w perspektywie ostatnich 12 miesięcy (Agencja Rozwoju Pomorza, 2013).

Krzysztof Obłój oraz Aleksandra Wąsowska przeprowadzili badania koncentrujące się na uwarunkowaniach strategii umiędzynarodowienia polskich firm niefinansowych działających na Giełdzie Papierów Wartościowych w Warszawie. Na podstawie powszechnie publikowanych danych, w tym sprawozdań finansowych, autorzy dokonali analizy stopnia, kierunku oraz formy internacjonalizacji 202 spółek giełdowych. W próbie badawczej znalazło 
się 155 (76,7\%) przedsiębiorstw prowadzących ekspansje na rynki zagranicznych, z których $78(50,3 \%)$ wykorzystywało kapitałowe formy umiędzynarodowienia. Sredni poziom umiędzynarodowienia, mierzonego jako udział sprzedaży zagranicznej w przychodach ogółem, wyniósł $21 \%$ dla wszystkich firm objętych badaniem. Poddane analizie zostały również główne kierunki kapitałowej ekspansji przedsiębiorstw, które koncentrowały się w Europie Środkowo-Wschodniej oraz krajach należących do Unii Europejskiej (Obłój i Wąsowska, 2010).

Proces internacjonalizacji z perspektywy przedsiębiorstw dokonujących bezpośrednich inwestycji zagranicznych stał się przedmiotem analizy zespołu Włodzimierza Karaszewskiego. W ramach realizacji w latach 2007-2008 projektu pt. Bezpośrednie inwestycje zagraniczne polskich przedsiębiorstw (skala, struktura, motywy i uwarunkowania, znaczenie dla konkurencyjności) przeprowadzono badania, którymi objęto 102 firmy zaangażowane kapitałowo na rynkach zagranicznych. Dominujaccy udział w próbie badawczej (70\%) miały podmioty ze stuprocentowym kapitałem polskim (Karaszewski, 2008, s. 15-18).

Kluczowym aspektem prowadzonej analizy było określenie stopnia internacjonalizacji polskich inwestorów bezpośrednich. Wykorzystany w tym celu syntetyczny wskaźnik transnacjonalizacji (ang. transnationality index) wskazuje, że największa część respondentów (44\%) charakteryzowała się średnim poziomem umiędzynarodowienia. Drugą pod względem wielkości grupe $(25 \%)$ stanowiły przedsiębiorstwa, które osiągnęły niską wartość omawianego indeksu. Znacznie mniejszy udział w próbie badawczej miały podmioty charakteryzujac sie wysokim (18\%) bądź bardzo wysokim $(13 \%)$ poziomem internacjonalizacji. Dekompozycja wskaźnika transnacjonalizacji wskazuje, że decydujący wpływ na jego kształt miał niski poziom aktywów zagranicznych w ich ogólnej strukturze, a także największy udział podmiotów (44\%) zatrudniających mniej niż $10 \%$ pracowników na rynkach zagranicznych (Karaszewski, 2008 s. 19-20).

Główne kierunki ekspansji zagranicznej polskich inwestorów bezpośrednich zostały przeanalizowane na podstawie danych o lokalizacji ich spółek zależnych. Zdecydowana większość inwestycji $(60 \%)$ kon- centrowała się w krajach Unii Europejskiej, w tym 59\% w krajach UE-15. Znaczna cześś firmy bezpośredniego inwestowania $(22 \%)$ tworzona była również na rynkach Europy Środkowo-Wschodniej. Analiza struktury 247 inwestycji dokonanych przez respondentów wskazuje, że dominujacy udział (78\%) miały przedsięwzięcia tworzone od podstaw (ang. greendfield investment), które były jedynym źródłem kapitałowego zaangażowania $64 \%$ przedsiębiorstw (Karaszewski, 2008, s. 20-23).

W 2012 roku Włodzimierz Karaszewski $\mathrm{z}$ zespołem kontynuował badania w ramach projektu naukowego pt. Aktywność inwestycyjna polskich przedsiębiorstw za granica - czynniki i skutki, którymi objęte zostały 64 podmioty ze specjalnie przygotowanej bazy polskich inwestorów bezpośrednich. Zdecydowana większość analizowanych przedsiębiorstw $(61,7 \%)$ funkcjonowała, opierając się wyłącznie na polskim kapitale (Karaszewski, 2013, s. 17).

Stopień internacjonalizacji został zmierzony dla próby 43 firm, które udzieliły odpowiedzi pozwalajaccej obliczyć indeks transnacjonalizacji. Uzyskane wyniki wskazują, że zdecydowana większość respondentów $(62,8 \%)$ osiągnęła średni poziom umiędzynarodowienia. W odniesieniu do wcześniejszego badania, znacznie zmniejszył się udział przedsiębiorstw charakteryzujacych sie wysokim albo bardzo wysokim poziomem internacjonalizacji, które stanowiły niespełna $12 \%$ próby badawczej. Analiza mniej zagregowanych danych pozwala zauważyć, że w przypadku największej części respondentów $(44,7 \%)$ sprzedaż zagraniczna mieściła się w przedziale 10-29\% przychodów ogółem.

Wyższy stopień umiędzynarodowienia sprzedaży obserwowany był dla $34 \%$ przedsiębiorstw uczestniczących $\mathrm{w}$ badaniu. Uzyskane wyniki wskazują również, że średniemu poziomowi internacjonalizacji aktywów oraz zatrudnienia towarzyszył spadek liczby podmiotów, które osiągały wysoką wartość tych wskaźników w odniesieniu do poprzedniego badania (Karaszewski, 2013, s. 18).

Analiza 279 podmiotów bezpośredniego inwestowania pozwoliła na określenie kierunków kapitałowej ekspansji grupy przedsiębiorstw uczestniczących w badaniu. Proces internacjonalizacji w największym stopniu koncentrował się w krajach Unii Europejskiej, gdzie zlokalizowano 
$73 \%$ spółek zależnych, w tym zdecydowana większość $(68 \%) \mathrm{z}$ nich funkcjonowała na rynkach UE-15. Dominujący udział miały państwa sąsiadujące z Polską (szczególnie Niemcy), jak również Francja, Belgia oraz Szwajcaria. Zasadnicza zamiana, w porównaniu do wcześniejszych badań zespołu Włodzimierza Karaszewskiego, dotyczyła struktury inwestycji w przypadku których dominowały $(51,8 \%)$ fuzje oraz przejęcia (ang. brownfield investment) (Karaszewski, 2013, s. 19)

Wieloaspektowa analiza procesu internacjonalizacji została przeprowadzona w 2008 roku przez Marzannę Katarzynę Witek-Hajduk w ramach projektu pt. Modele internacjonalizacji polskich przedsiębiorstw $w$ warunkach akcesji Polski do Unii Europejskiej. Kompleksowe badania empiryczne koncentrowały sie na, istotnych $\mathrm{z}$ punktu widzenia niniejszego artykułu, aspektach umiędzynarodowienia, $\mathrm{w}$ tym jego poziomie, kierunkach i formach, ale również podejmowały problematykę m.in. strategii konkurencyjności oraz determinantów ekspansji międzynarodowej. W próbie badawczej znalazło się 257 (176 średnich i 81 dużych) przedsiębiorstw działających w branży elektromaszynowej, spożywczej oraz chemicznej, które nie były spółkami zależnymi podmiotów zagranicznych (Witek-Hajduk, 2010, s. 183-187).

Stopień internacjonalizacji, mierzony liczba obsługiwanych przez respondentów rynków zagranicznych, kształtował sie na średnim poziomie. Większość podmiotów z próby badawczej $(45,1 \%)$ deklarowała prowadzenie działalności na 4-10 rynkach. Znaczna część przedsiębiorstw (30,8\%) dokonywała ekspansji do więcej niż 10 krajów, w tym $12,1 \% \mathrm{z}$ nich osiagnęło bardzo wysoki poziom dywersyfikacji geograficznej (powyżej 25 rynków zagraniczny). Badania wskazują również, że relatywnie spora grupa respondentów $(21,8 \%)$ była zaangażowana na nie więcej niż 3 rynkach. Dodatkowo, uzyskane wyniki wskazują, że przedsiębiorstwa duże (zatrudniające powyżej 250 pracowników) charakteryzowały sie wyższym poziomem umiędzynarodowienia w analizowanej próbie badawczej (WitekHajduk, 2010, s. 245).

Głównym kierunkiem ekspansji międzynarodowej była Unia Europejska, w tym szczególnie kraje UE-15, w których zaangażowana była największa $(84,4 \%)$ grupa przedsiębiorstw. Respondenci wskazywali również najczęściej (58\%) jedno z państw UE-15 jako pierwszy rynek prowadzonej działalności zagranicznej. W pozostałych państwach członkowskich Unii Europejskiej zaangażowanych było $67,3 \%$ przedsiębiorstw, natomiast tylko $13 \%$ próby badawczej rozpoczynało $\mathrm{w}$ jednym $\mathrm{z}$ nich ekspansję międzynarodową. Autorka zwraca uwage, że istotnym rynkiem zbytu z perspektywy prowadzonej działalności gospodarczej były kraje Europy Wschodniej, w tym Rosja $(39,7 \%)$ oraz Ukraina $(38,5 \%)$. Uzyskane wyniki wskazuja, że w okresie 2003-2008 istotnie wzrosła atrakcyjność rynków azjatyckich, szczególnie $\mathrm{Z}$ perspektywy dużych przedsiebiorstw (Witek-Hajduk, 2010, s. 231-232).

Przedmiotem prowadzonych przez Marzannę Katarzynę Witek-Hajduk badań empirycznych były również formy internacjonalizacji. Dominującą rolę odgrywała działalność eksportowa, którą prowadziły niemal wszystkie przedsiębiorstwa $(98,1 \%)$. Znaczna czéść respondentów, dokonujac ekspansji międzynarodowej, decydowała sie na przedsiewziecia handlowe $(19,5 \%)$ oraz produkcyjne $(10,1 \%)$ wspólnie z partnerami zagranicznymi. Inne formy kapitałowego zaangażowania, w tym wymagające większych nakładów finansowych, były relatywnie rzadziej wykorzystywane i dotyczyły głównie dużych przedsiębiorstw. Zwrócono również uwagę na bierną internacjonalizację, która nie jest uwzględniana w większości badań dotyczących umiędzynarodowienia polskich przedsiębiorstw. W tym przypadku dominujące znaczenie miał import, który wykorzystywany był przez $66,1 \%$ analizowanej próby badawczej (Witek-Hajduk, 2010, s. 231-232).

W 2010 roku Mirosław Jarosiński dokonał analizy specyfiki procesu internacjonalizacji w Polsce, którymi objął 121 średnich oraz 120 dużych przedsiębiorstw prowadzacych działalność na rynkach zagranicznych pochodzących z losowo dobranej próby 588 podmiotów gospodarczych. Wśród 241 respondentów zdecydowana większość (77\%) oparta była na całkowitym albo przeważającym kapitale polskim oraz dominowały przedsiębiorstwa młode, powstałe w ciągu ostatnich 20 lat (Jarosiński, 2013, s. $277-280)$.

Jednym z głównych elementów badania empirycznego była weryfikacja hipotezy zakładającej niski poziom umiędzynarodowienia polskich przedsiębiorstw. Autor, 
wykorzystując wypracowane na gruncie literatury przedmiotu narzędzia analityczne, prezentuje wiele wymiarów i sposobów pomiaru omawianego zjawiska. Pierwszy, mający złożony charakter, indeks transnacjonalizacji osiągnął wartość poniżej 20 dla 145 respondentów, którzy udzielili odpowiedzi niezbędnych do jego policzenia. Odmienne wnioski możliwe są do wyciągnięcia na podstawie analizy udziału sprzedaży zagranicznej do ogółu obrotów 171 podmiotów z próby badawczej, który, kształtując się na poziomie $44,8 \%$, wskazuje na średni stopień internacjonalizacji (Jarosiński, 2013, s. 291-293).

Analiza pozostałych, wynikajaccych z teorii, wskaźników potwierdza postawioną przez Mirosława Jarosińskiego hipoteze o niskim stopniu umiędzynarodowienia polskich przedsiębiorstw. Wskazuje na to niewielka średnia liczba rynków zagranicznych, które w przypadku większości respondentów $(65,6 \%)$ zlokalizowane są w Europie (Jarosiński, 2013, s. 286-287). Relatywnie mały poziom dywersyfikacji geograficznej potwierdzają dane dotyczące głównych kierunków ekspansji międzynarodowej. Najbardziej atrakcyjny, z perspektywy 129 przedsiębiorstw, które poprawnie udzieliły odpowiedzi w tej części ankiety, jest rynek niemiecki. Kolejnymi krajami pod względem częstotliwości ich wyboru przez polskie przedsiębiorstwa są Czechy $(35 \%)$, Wielka Brytania (33\%) oraz Litwa $(32 \%)$. Mniejsze znaczenie miały rynki krajów pozaeuropejskich, wśród których najwięcej przedsiębiorstw działało w Stanach Zjednoczonych (10,8\%) (Jarosiński, 2013, s. 299-300).

Wyniki badań empirycznych wskazują, że polskie przedsiębiorstwa, prowadząc ekspansje na rynki zagraniczne, wykorzystuja mało zaawansowane formy internacjonalizacji.

Szczególnie istotny, $\mathrm{z}$ perspektywy przedsiębiorstw podejmujących aktywność na rynkach zagranicznych, jest eksport zarówno bezpośredni (86\% próby badawczej), jak również pośredni (50\%). Znacznie mniejszą popularnością cieszyły się kapitałowe formy internacjonalizacji, wymagajace relatywnie dużych nakładów finansowych, w tym m.in. filie handlowe $(13 \%)$ oraz filie produkcyjne $(4 \%)$. Marginalne znaczenie $\mathrm{w}$ procesie umiędzynarodowienia polskich przedsiębiorstw miały takie formy jak sprzedaż licencyjna $(2 \%)$ oraz umowy franczyzy (ang. franchising) (Jarosiński, 2013, s. 295).

Ostatnie, omówione na potrzeby niniejszego artykułu badanie, zostało przeprowadzone w latach 2013-2014 przez zespó1 Krzysztofa Wacha w ramach projektu pt. Ściezki internacjonalizacji przedsiebiorstwa $w$ krajach wyszehradzkich. Eksploracja regionalnej specyfiki. Analizą objęte zostały przedsiębiorstwa ze wszystkich krajów Grupy Wyszehradzkiej, w tym 216 polskich firm, które poprawnie wypełniły przygotowany kwestionariusz (Wach, 2014, s. 38-40). Zdecydowana większość $\mathrm{z}$ nich (63\%) prowadziła działalność w wymiarze globalnym, decydując się na ekspansje na rynki krajów Unii Europejskiej, jak również do pozostałych państw (Daszkiewicz i Wach, 2014, s. 88).

Prowadzone badania empiryczne wskazują, że polskie przedsiębiorstwa, prowadząc działalność na rynkach zagranicznych, wykorzystują mało zaawansowane formy internacjonalizacji. Dominujace znaczenie miał eksport bezpośredni, który stosowany był przez największą grupe respondentów. Znacznie mniej popularne były kapitałowe formy ekspansji międzynarodowej, które wymagają znacznie większych nakładów finansowych oraz są związane $\mathrm{z}$ wyższym poziomem ryzyka. Potwierdzono również występowanie dodatniej korelacji pomiędzy wielkością przedsiębiorstwa a wykorzystywanymi formami internacjonalizacji. Oznacza to, że bezpośrednie inwestycje zagraniczne wykorzystywane są głównie przez średnie i duże przedsiębiorstwa (Wach, 2014, s. 77-78).

Jednym $z$ aspektów badań empirycznych było wskazanie dominującej strategii umiędzynarodowienia polskich przedsiębiorstw. Uzyskane wyniki wskazują, że największa grupa respondentów $(35,8 \%)$ dokonuje ekspansji międzynarodowej zgodnie z sekwencyjnym modelem internacjonalizacji, stopniowo zwiększając zaangażowanie na rynkach zagranicznych. W próbie badawczej większość przedsiębiorstw $(58 \%)$ rozpoczynała działalność na rynkach zagranicznych w ciągu pierwszych trzech lat funkcjonowania. Zdecydowana większość z nich, aż 76 podmiotów, rozpoczynała ekspansję międzynarodową w pierwszym roku od momentu założenia (Daszkiewicz i Wach, 2014, s. 92). 


\section{Wyniki badań empirycznych dotyczących umiędzynarodowienia polskich przedsiębiorstw}

W niniejszej części pracy koncentruje się na omówieniu wyników analizy procesu internacjonalizacji polskich przedsiębiorstw w kontekście wcześniej prezentowanego dorobku literatury przedmiotu. W tym celu wykorzystana została baza danych przygotowana na potrzeby projektu pt. Wprowadzenie euro a konkurencyjność polskich przedsiębiorstw na zagranicznych rynkach, realizowanego na Wydziale Zarządzania Uniwersytetu Warszawskiego, w ramach grantu naukowego przyznanego przez Narodowe Centrum Nauki (decyzja 2011/03/D/HS4/01954). Prowadzone przez zespół pod kierunkiem Grzegorza Tchorka badania empiryczne koncentrowały się na istotnych aspektach funkcjonowania polskich przedsiębiorstw w 2013 roku.

Ankieta opracowana na potrzeby realizacji projektu, zgodnie $\mathrm{z}$ zawartym porozumieniem, została oparta na wcześniejszych badaniach pt. European Firms in Global Economy (EFIGE) przeprowadzonych przez think-thank Bruegel w siedmiu krajach Unii Europejskiej. Przygotowany kwestionariusz wykorzystywał 50 oryginalnych pytań z sześciu obszarów tj. struktura firmy, siła robocza, innowacyjność, proces umiędzynarodowienia, struktura rynku oraz sposób finansowania. Dane zgromadzono w okresie 2014-2015, wykorzystując w tym celu wspomagane komputerowo metody ilościowe, tj. wywiad telefoniczny (ang. Computer Assisted Telephone Interviewing, CATI) oraz wywiad w postaci ankiet udostępnianych internetowo (ang. Computer Assisted Web Interviewing, CAWI).

Badania empiryczne pozwolity na uzyskanie unikatowej bazy danych skupiających 960 przedsiębiorstw, które udzieliły odpowiedzi na zawarte w kwestionariuszu pytania. Autor niniejszego artykułu, na potrzeby prowadzonej analizy, dokonal wstepnej walidacji, która pozwoliła na wyeliminowanie występujących błędów i niespójności oraz usunął obserwacje uniemożliwiające analizę procesu internacjonalizacji. Po pierwsze, wyłączono z kolejnych etapów badań przedsiębiorstwa, które udzieliły wzajemnie wykluczajacych się odpowiedzi w poszczególnych sekcjach ankiety. Po drugie, procedurę tę zastosowano również w odniesieniu do podmiotów, które nie wskazały daty rozpoczęcia działalności bądź zostały utworzone po 2013 roku. Po trzecie, ze względu na charakter prowadzonych badań, analiza została ograniczona do respondentów, którzy podejmowali działalność na rynkach zagranicznych. Po czwarte, wyeliminowane zostały przedsiębiorstwa, które nie udzieliły żadnej odpowiedzi dotyczacej umiędzynarodowienia oraz nie podały liczby zatrudnianych pracowników.

Proces walidacji bazy danych pozwolił uzyskać próbę badawczą, w której znalazło się 776 polskich przedsiębiorstw prowadzących działalność na rynkach zagranicznych. Zawarte w kwestionariuszu ankiety pytanie dotyczące poziomu zatrudnienia umożliwiło, zgodnie z Zaleceniem Komisji Europejskiej z dn. 6 maja 2003 roku dotyczace definicji przedsiebiorstw mikro, małych i średnich $(2003 / 361 / W E$ w Dz.U. L 124 z 20.05.2003 s. 36-41), pogrupowanie respondentów ze względu na klasy wielkości. Widoczna w próbie badawczej nadreprezentacja średnich i dużych przedsiębiorstw, których udział wynosił odpowiednio $40,6 \%$ oraz $21,5 \%$, umożliwia porównanie uzyskanych wyników z perspektywy wielkości analizowanych podmiotów (por. tab. 1). Przeważająca większość respondentów (92\%), zgodnie z założeniami projektu badawczego, prowadziła działalność w obszarze przetwórstwa przemysłowego - na podstawie Polskiej Klasyfikacji Działalności (PKD). Na poziomie podziału administracyjnego, widoczny jest relatywnie wysoki poziom dopasowania próby badawczej do danych dotyczących całej populacji polskich przedsiębiorstw.

Kluczowym aspektem, z perspektywy analizy procesu internacjonalizacji, jest pomiar poziomu umiędzynarodowienia badanej grupy przedsiębiorstw. Jednym z głównych wskaźników wykorzystywanych $\mathrm{w}$ tym celu, ugruntowanym w literaturze przedmiotu, jest indeks transnacjonalizacji sprzedaży, pozwalający ocenić rzeczywiste zaangażowanie w działalność międzynarodową. Wyniki badań empirycznych wskazuja, że średni udział przychodów ze sprzedaży zagranicznej w całkowitej wartości obrotów wynosił $34,7 \%$ dla próby badawczej (por. rys. 1). Na podstawie dokonanego wcześniej przegladu literatury należy określić, że respondenci charakteryzują się średnim poziomem internacjonalizacji. Mimo to, wartość omawianego wskaźnika 
Tabela 1. Charakterystyka próby badawczej ze względu na klasy wielkości w 2013 roku

\begin{tabular}{|l|c|c|c|c|}
\hline \multicolumn{1}{|c|}{ Wyszczególnienia } & $\begin{array}{c}\text { Przedsiębior- } \\
\text { stwa ogółem }\end{array}$ & $\begin{array}{c}\text { Przedsiębior- } \\
\text { stwa małe }\end{array}$ & $\begin{array}{c}\text { Przedsiębior- } \\
\text { stwa średnie }\end{array}$ & $\begin{array}{c}\text { Przedsiębior- } \\
\text { stwa duże }\end{array}$ \\
\hline $\begin{array}{l}\text { Liczebność przedsiębiorstw } \\
\text { w próbie badawczej }\end{array}$ & 776 & 294 & 315 & 167 \\
\hline $\begin{array}{l}\text { Udział przedsiębiorstw } \\
\text { w próbie badawczej (w \%) }\end{array}$ & 100 & 37,9 & 40,6 & 21,5 \\
\hline $\begin{array}{l}\text { Liczba przedsiębiorstw } \\
\text { w Polsce ogółem (w tys.) }\end{array}$ & 4070,3 & 4036,1 & 29,6 & 4,5 \\
\hline $\begin{array}{l}\text { Udział przedsiębiorstw } \\
\text { w Polsce (ogólem (w \%) }\end{array}$ & 100 & 99,2 & 0,7 & 0,1 \\
\hline
\end{tabular}

Źródło: badania ankietowe w ramach projektu „Wprowadzenie euro a konkurencyjność polskich przedsiębiorstw na zagranicznych rynkach" (decyzja NCN nr 2011/03/D/HS4/01954) oraz dane Głównego Urzędu Statystycznego.

Rysunek 1. Indeks transnacjonalizacji sprzedaży dla próby badawczej w 2013 roku (w \%) (n=776)

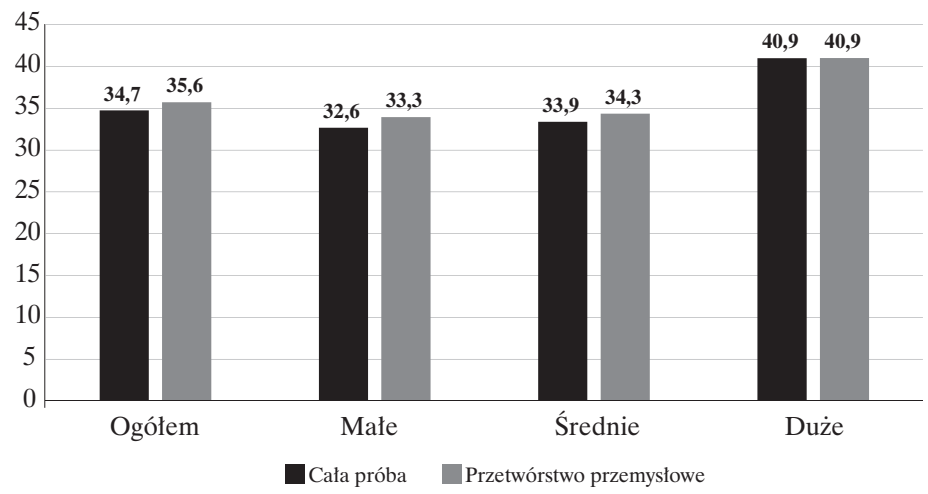

Źródło: badania ankietowe w ramach projektu „Wprowadzenie euro a konkurencyjność polskich przedsiębiorstw na zagranicznych rynkach" (decyzja NCN nr 2011/03/D/HS4/01954).

dla większości analizowanych podmiotów $(57 \%)$ nie przekracza $30 \%$. Widoczna jest również, zgodnie $\mathrm{z}$ wynikami wcześniejszych badaniami empirycznymi, dodatnia korelacja pomiędzy stopniem zaangażowania na rynkach zagranicznych a wielkością przedsiębiorstw.

Analiza poziomu umiędzynarodowienia oparta na pojedynczym wskaźniku charakteryzuje się relatywnie wysokim prawdopodobieństwem niepoprawnej interpretacji wyników, a w konsekwencji wyciągnięciem błędnych wniosków (Sullivan, 1994, s. 325-327). Konieczna weryfikacja stopnia zaangażowania przedsiębiorstw $\mathrm{w}$ działalność o charakterze międzynarodowym możliwa jest na podstawie danych dotyczących liczby obsługiwanych rynków zagranicznych. Zdecydowana większość respon- dentów $(71,3 \%)$ spośród 669 podmiotów, które udzieliły odpowiedzi na zadane pytanie, prowadziła ekspansje do nie więcej niż 9 państw, przy czym badane przedsiębiorstwa średnio zaangażowane były na 7,6 rynkach zagranicznych. Ograniczony stopień dywersyfikacji geograficznej świadczy o niskim poziomie internacjonalizacji. Wyższe wartości omawianego wskaźnika dla dużych przedsiębiorstw potwierdzają występowanie wskazanej wcześniej zależności.

Podmioty gospodarcze biorące udział w badaniach poproszone zostały również o wskazanie kierunków ekspansji międzynarodowej oraz ich udziału w łącznej wartości eksportu. Dominujące znaczenie miał rynek wewnętrzny, na którym skupiało się średnio $86,6 \%$ działalności zagranicznej 
Rysunek 2. Kierunki ekspansji eksportowej przedsiębiorstw w 2013 roku (w \%) (n=652)

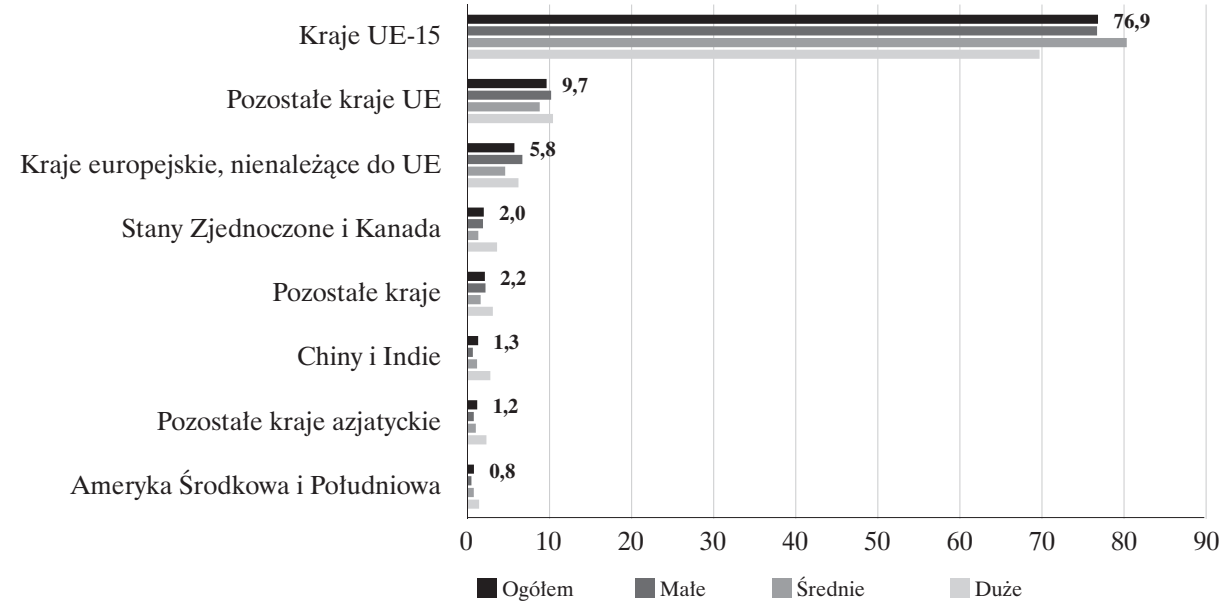

Źródło: badania ankietowe w ramach projektu „Wprowadzenie euro a konkurencyjność polskich przedsiębiorstw na zagranicznych rynkach" (decyzja NCN nr 2011/03/D/HS4/01954).

652 respondentów, którzy wypełnili tę część kwestionariusza (por. rys. 2). Mimo zbliżonych regulacji występujących pomiędzy krajami członkowskimi Unii Europejskiej, zdecydowana większość sprzedaży $(76,9 \%)$ koncentruje się w krajach UE-15. Marginalny udział, zgodnie m.in. z modelem sekwencyjnego procesu internacjonalizacji, mają rynki odległe pod względem geograficznym, a także kulturowym, w których zaangażowane są pojedyncze, w większości duże przedsiębiorstwa.

Badania empiryczne koncentrują się na problematyce konkurencyjności polskich przedsiębiorstw na rynkach zagranicznych Z perspektywy prowadzonej działalności eksportowej. Mimo to, zawarte w kwestionariuszu pytanie dotyczące sposobu sprzedaży produktów bądź usług umożliwia dokonanie analizy form internacjonalizacji. Niemal wszystkie przedsiębiorstwa z próby badawczej (97\%), niezależnie od poziomu zatrudnienia, wykorzystują eksport bezpośredni w działalności prowadzonej na rynkach zagranicznych. Uzyskane wyniki wskazują również, że respondenci w mniejszym stopniu prowadzili ekspansje poprzez pośredników z kraju macierzystego $(11,1 \%)$, w tym forma ta wykorzystywana była głównie przez duże przedsiębiorstwa (13,7\% z nich). Zbliżoną częstotliwością wykorzystywania przez badane podmioty $(9,9 \%)$ oraz podobnym, z perspektywy klas wielkości, rozkładem charakteryzował się eksport bezpośrednio z kraju trzeciego, w którym odbywa się proces produkcyjny. Należy przyjąć, że ta forma internacjonalizacji związana jest $\mathrm{z}$ kapitałowym zaangażowaniem na rynkach zagranicznych i jej relatywnie niewielki udział w ekspansji międzynarodowej może świadczyć o stosowaniu mało zaawansowanych metod umiędzynarodowienia.

Postęp technologiczny towarzyszący procesowi globalizacji oraz liberalizacja handlu przyczyniają się do zmniejszania barier związanych z ekspansją międzynarodową. Wpływa to m.in. na tempo internacjonalizacji, którego średni poziom wynosi 7,5 roku dla 674 przedsiębiorstw. Wyniki prowadzonych badań wskazują, że znaczna część respondentów (46,1\%), określanych terminem „wcześnie umiędzynarodowionych”, rozpoczyna działalność na rynkach zagranicznych w ciagu trzech pierwszych lat funkcjonowania. Przyśpieszona internacjonalizacja w większym stopniu widoczna jest w małych $(50,4 \% \mathrm{z}$ nich) oraz średnich (44,6\% z nich) podmiotach, niż w dużych przedsiębiorstwach (40,5\% z nich).

$\mathrm{W}$ ramach literatury przedmiotu $\mathrm{w}$ coraz większym stopniu rozwijana jest koncepcja „urodzonych globalistów” (ang. born global), odnosząca się do młodych przedsiębiorstw prowadzących działalność w wymiarze globalnym. Mimo mnogości dostępnych definicji oraz sposobów pomiaru tego zjawiska, na potrzeby niniejszego artykułu przyjęto, że terminem tym będziemy określać podmioty, które jednocześnie stosują 
Tabela 2. Charakterystyka próby badawczej ze względu na tempo internacjonalizacji oraz udział sprzedaży zagranicznej w ogóle obrotów wyróżnionych grup przedsiębiorstw

\begin{tabular}{|l|c|c|c|c|c|c|}
\hline \multirow{2}{*}{$\begin{array}{c}\text { Wielkość } \\
\text { przedsiębiorstwa }\end{array}$} & \multicolumn{2}{|c|}{ Urodzeni globaliści } & \multicolumn{2}{c|}{$\begin{array}{c}\text { Wcześnie } \\
\text { umiędzynarodowieni }\end{array}$} & \multicolumn{2}{c|}{ Próba ogółem } \\
\cline { 2 - 7 } & liczebnośćc & $\begin{array}{c}\text { sprzedaż } \\
\text { eksportowa } \\
\text { (w \%) }\end{array}$ & liczebność & $\begin{array}{c}\text { sprzedaż } \\
\text { eksportowa } \\
\text { (w \%) }\end{array}$ & liczebność & $\begin{array}{c}\text { sprzedaż } \\
\text { eksportowa } \\
\text { (w \%) }\end{array}$ \\
\hline Ogółem & 193 & 52,4 & 311 & 37,0 & 776 & 34,7 \\
\hline Małe & 86 & 51,2 & 138 & 36,3 & 294 & 32,6 \\
\hline Średnie & 69 & 53,2 & 120 & 35,3 & 315 & 33,3 \\
\hline Duże & 38 & 53,6 & 53 & 42,9 & 167 & 40,9 \\
\hline
\end{tabular}

Źródło: badania ankietowe w ramach projektu „,Wprowadzenie euro a konkurencyjność polskich przedsiębiorstw na zagranicznych rynkach" (decyzja NCN nr 2011/03/D/HS4/01954).

przyśpieszoną internacjonalizację oraz osiągają przychody ze sprzedaży zagranicznej na poziomie $25 \%$ obrotów ogółem. Uzyskane wyniki wskazują, że 28,6\% z 674 respondentów, którzy podali datę rozpoczęcia działalności oraz ekspansji eksportowej, spełnia łacznie dwa przedstawione powyżej kryteria. Przedsiębiorstwa te charakteryzują się znacznie wyższym stopniem umiędzynarodowienia, który kształtuje się, na podstawie indeksu transnacjonalizacji sprzedaży, na średnim poziomie $52,4 \%$. Zgodnie z wcześniejszymi obserwacjami oraz przytoczonymi badaniami empirycznymi również w grupie podmiotów typu „born global” występuje dodatnia korelacja między klasą wielkości a udziałem przychodów ze sprzedaży zagranicznej w całkowitej wartości obrotów.

\section{Podsumowanie}

Problematyka umiędzynarodowienia działalności przedsiębiorstwa staje się jednym $\mathrm{z}$ głównych obszarów zainteresowania ekonomii oraz nauki o zarządzaniu. Rosnąca liczba artykułów oraz monografii na ten temat wskazuje, że omawiane zjawisko w coraz większym stopniu kształtuje procesy gospodarcze oraz wpływa na wzajemne relacje między podmiotami. Głównych przyczyn należy poszukiwać w liberalizacji handlu, która istotnie zmniejszyła bariery i obciążenia, a także w postępie technologicznym, który nie tylko zmniejszył koszty wzajemnej wymiany, lecz także stymulował proces fragmentaryzacji produkcji. W przypadku polskich przedsiębiorstw kluczowym aspektem była akcesja do Unii Europejskiej, dająca dostęp do rynku wewnętrznego.
Ewolucja teorii z zakresu handlu międzynarodowego oraz produkcji międzynarodowej wskazuje na zwiększenie roli pojedynczych podmiotów $\mathrm{w}$ analizie oraz wieloaspektowy charakter omawianych procesów. Pozwala to na określenie potencjalnych korzyści i kosztów związanych z ekspansją międzynarodową, z perspektywy zarówno całej gospodarki, jak i przedsiębiorstwa. Kluczowym aspektem prowadzonych badań było wyodrębnienie grupy czynników determinujacych wejście na rynki zagraniczne. Przesłanki i motywy umiędzynarodowienia, wpływające na pozycję konkurencyjną przedsiębiorstwa, podlegają stałej zmianie i uzależnione są m.in. od branży oraz charakteru prowadzonej działalności.

Przeprowadzony na potrzeby niniejszego artykułu przegląd wybranych badań empirycznych dotyczących internacjonalizacji polskich przedsiębiorstw umożliwia wyodrębnienie najważniejszych aspektów omawianego procesu. Po pierwsze, stopień umiędzynarodowienia kształtuje się na relatywnie niskim poziomie, ale widoczna jest tendencja wzrostu udziału przychodów ze sprzedaży zagranicznej w obrotach ogółem. Po drugie, polskie przedsiębiorstwa, wchodząc na rynki zagraniczne, wybierają głównie mało zaawanasowane formy internacjonalizacji, które nie wymagają wysokich nakładów kapitałowych. Po trzecie, głównym kierunkiem ekspansji międzynarodowej są kraje bliskie pod względem geograficznym oraz kulturowym, w szczególności państwa członkowskie Unii Europejskiej. Po czwarte, widoczny jest wzrost tempa umiędzynarodowienia polskich przedsiębiorstw, które znacznie wcześniej decydują się na wejście na rynki zagraniczne. Po piąte, w literaturze 
przedmiotu zwraca się uwagę na zjawisko wczesnego umiędzynarodowienia, dostrzegając wzrost liczby podmiotów określanych mianem „urodzonych globalistów”.

Zrealizowane $\mathrm{w}$ ramach projektu pt. Wprowadzenie euro a konkurencyjność polskich przedsiębiorstw na rynkach zagranicznych badania empiryczne potwierdzaja większość wniosków, wynikających z krytycznego przeglądu literatury przedmiotu. Uzyskane wyniki wskazują, że podmioty gospodarcze w coraz większym stopniu angażują się w działalność zagraniczną, ale nadal wykorzystują mało zaawanasowane formy internacjonalizacji i koncentrują się na rynku wewnętrznym.

\section{Przypis}

1 Artykuł przygotowany w ramach projektu sfinansowanego ze środków Narodowego Centrum Nauki przyznanych na podstawie decyzji numer DEC-2011/03/D/HS4/01954. Autor składa serdeczne podziękowania dla dr. Grzegorza Tchorka, promotora pracy magisterskie pt. Proces internacjonalizacji polskich przedsiębiorstw, za pomoc merytoryczną i cenne uwagi do niniejszego artykułu.

\section{Bibliografia}

Agencja Rozwoju Pomorza (2007). Kondycja sektora MSP na Pomorzu. Raport z badania matych $i$ średnich przedsiębiorstw $w$ ramach Pomorskiego Obserwatorium Gospodarczego. Gdańsk.

Agencja Rozwoju Pomorza (2008). Dynamika sek tora MSP na Pomorzu. Raport $z$ badania matych $i$ średnich przedsiębiorstw $w$ ramach Pomorskiego Obserwatorium Gospodarczego II. Gdańsk.

Agencja Rozwoju Pomorza (2010). Sektor MSP na Pomorzu w warunkach pogorszenia koniunktury. Raport z badania matych $i$ średnich przedsiębiorstw w ramach Pomorskiego Obserwatorium Gospodarczego III. Gdańsk.

Agencja Rozwoju Pomorza (2013). Sektor MSP na Pomorzu $w$ warunkach spowolnienia tempa wzrostu gospodarczego. Raport z badania sektora MSP $w$ województwie pomorskim ze szczególnym uwzględnieniem przedsiębiorstw $w$ powiecie kościerskim. Gdańsk.

Bożyk, P., Misala, J. i Puławski, M. (1998). Międzynarodowe stosunki ekonomiczne. Warszawa: PWE.

Budnikowski, A. (2006). Międzynarodowe stosunki gospodarcze. Warszawa: PWE.

Caves, R.E. (1996). Multinational Enterprise and Economic Analysis. Cambridge: Cambridge University Press.
Cavusgil, S.T. (1984). Differences Among Exporting Firms Based on Their Degree of Internationalization. Journal of Business Research, 12(3).

Dunning, J.H. (2000). The eclectic paradigm as an envelope for economic and business theories of MNE activity. International Business Review, 9.

Cieślik, A., Michałek, J.J. i Michałek, A. (2012). Determinanty działalności eksportowej polskich przedsiębiorstw. Gospodarka Narodowa, 7-8.

Daszkiewicz, N. i Wach, K. (2014). Patterns of Business Internationalisation in Poland: Empirical Results from V4 Survey W: A. Durendez i K. Wach, Patterns of Business Internationalisation in Visegrad Countries In Search for Regional Specifics. Cartagena.

Dunning, J.H. (2003). Determinants of Foreign Direct Investment: Globalization-Induced Changes and the Role of Policies W: World Bank, Toward Pro-Poor Policies: Aid, Institutions and Globalization. Annual World Bank Conference on Development Europe.

Gorynia, M. (2007). Strategie zagranicznej ekspansji przedsiębiorstw. Warszawa: PWE.

Gorynia, M. i Jankowska, B. (2008). Klastry a międzynarodowa konkurencyjność i internacjonalizacja przedsiębiorstw. Warszawa: Difin.

Hymer, S. (1976). The international operations of national firms: A study of direct foreign investment. Cambridge: MIT Press.

Jarosiński, M. (2013). Procesy i modele internacjonalizacji polskich przedsiębiorstw. Warszawa: Oficyna Wydawnicza SGH.

Johanson, J. i Mattsson, L.G. (1998). Internationalization in industrial system - a network approach. W: N. Hood i J. Vahlne (red.), Strategies in global competition. Croom Helm.

Johanson, J. i Vahlne, J. (1977). The internationalization Process of the Firm - A Model of Knowledge Development and Increasing Foreign Market Commitments. Journal of International Business Studies, 8.

Johanson, J. i Vahlne, J. (1992). Management of foreign entry. Scandinavian International Business Review, 1(3).

Johanson, J. i Vahlne, J. (2009). The Uppsala internationalization process model revisited: From liability of foreignness to liability of outsidership. Journal of International Business Studies, 40.

Johanson, J., Wiedersheim-Paul, F. (1975). The Internationalization of the Firm - Four Swedish Case. Journal of Management Studies, 12(3).

Karaszewski, W. (2008). Wprowadzenie W: W. Karaszewski (red.), Bezpośrednie inwestycje zagraniczne polskich przedsiębiorstw. Toruń: Wydawnictwo „Dom Organizatora”

Karaszewski, W. (2013). Wprowadzenie W: W. Karaszewski (red.), Aktywność inwestycyjna pol- 
skich przedsiębiorstw za granica - czynniki $i$ skutki. Warszawa: PWE.

KPMG (2005). Ekspansja międzynarodowa polskich przedsiębiorstw. Raport.

Krugman, P. (1979). Increasing returns monopolistic competition, and international trade. Journal of International Economy, 9.

Krugman, P.R. (1981). Intra-industry Specialization and the Gains from Trade. Journal of Political Economy, 89(5).

Krugman, P.R. i Obstfeld, M. (2007). Ekonomia międzynarodowa. Teoria i polityka 1. Warszawa: PWN.

Krzewicki, P. (2016). Proces internacjonalizacji polskich przedsiębiorstw. Warszawa, praca magisterska.

Melitz, M. (2003). The impact of trade intra industry reallocations and aggregate industry productivity. Econometrica, 71(6).

Nowak, A.Z. i Niewiadomska, A. (2014). Międzynarodowe stosunki gospodarcze. Warszawa, wersja elektroniczna.

Oczkowska, R. (2013). Międzynarodowa ekspansja przedsiebiorstw w warunkach globalizacji. Motywy Strategie - Tendencje. Warszawa: Difin.

Obłój, K. i Wąsowska, A. (2010). Uwarunkowania strategii umiedzynarodowienia polskich firm giełdowych. W: R. Kupski (red.), Zarządzanie strategiczne. Strategie organizacji. Prace Naukowe WWSZiP.

Rymarczyk, J. (2004). Internacjonalizacja i globalizacja przedsiębiorstwa. Warszawa: PWE.

Smith, A. (2007). Badania nad natura i przyczynami bogactwa narodów 2. Warszawa: Wydawnictwo Naukowe PWN.

Sullivan, D. (1994). Measuring the Degree of Internationalization of a Frim. Journal of International Business Studies, 25(2).

Zielińska-Głębocka, A. i Rynarzewski, T. (2008). Miedzynarodowe stosunki gospodarcze. Warszawa: Wydawnictwo Naukowe PWN

Vernon, R. (1966). International Trade and International Investment in the Product Cycle. Quarterly Journal of Economics, 80(2).

Wach, K. (2014). Research Methodology of the Field Study on the Firm-Level Internationalisation in Visegrad Countries W: A. Duréndez i K. Wach, Patterns of Business Internationalisation in Visegrad Countries - In Search for Regional Specifics. Cartagena. Wasowska, A. (2011). Zasobowe uwarunkowania umiędzynarodowienia polskich spótek giełdowych. Warszawa: rozprawa doktorska

Witek-Hajduk, M.K. (2010). Strategie internacjonalizacji polskich przedsiębiorstw w warunkach akcesji Polski do Unii Europejskiej. Warszawa: Oficyna Wydawnicza SGH. 